Volume 5 Nomor. 1, April 2020

P -ISSN : 2541-1179, E-ISSN : 2581-1711

Ojs :http://journal.uin-alauddin.ac.id/index.php/instek/index

Email : instek@uin-alauddin.ac.id

\title{
PENGGUNAAN METODE LINEAR PROGRAMMING PADA OPTIMASI POMPA BERTENAGA HYBRID GENERATOR DIESEL - SEL SURYA - BATERAI
}

\author{
ABDULLAH BASALAMAH', TANRIDIO S. D. ABDURRAHMAN ${ }^{2}$, \\ SAIDAH SUYUTI ${ }^{3}$ \\ Jurusan Elektro Fakultas Teknik Universitas Muslim Indonesi ${ }^{1,2,3}$, \\ J1. Urip Sumoharjo 90231 Indonesia, (telp 0411-443685; fax: 0411-443685; e- \\ mail : abdullah.basalamah@umi.ac.id, tanridiosilviati.da@umi.ac.id, \\ saidah@ymail.com
}

\begin{abstract}
ABSTRAK
Pompa air alternatif yang digerakkan oleh tenaga hybrid generator diesel - sel surya - baterai dibutuhkan untuk antisipasi terputusnya pasokan listrik PLN. Optimasi penggunaan bahan bakar untuk menggerakkan pompa air tersebut menjadi tujuan dari riset ini dengan menerapkan metode linear programming. Permintaan air oleh pelanggan skala rumah tangga dan daya listrik yang diperlukan dalam menggerakkan pompa air bertenaga hybrid (PATH) ini menjadi pertimbangan kendala-kendala dalam melakukan optimasi. Batasan lainnya adalah mengkondisikan penampungan air terisi full setiap saat dan kapasitas baterai $100 \%$ di setiap awal hari. Inisialisasi awal dari tangki air dan baterai menjadi penentu optimumnya penggunaan bahan bakar oleh generator diesel.
\end{abstract}

Kata Kunci: Optimasi, linear programming, daya hybrid, generator diesel, sel surya, baterai

\section{PENDAHULUAN}

Indonesia merupakan negara yang bermandikan cahaya matahari dan sekaligus juga wilayah yang rawan bencana alam. Tidak jarang saat bencana alam menerjang mengakibatkan terganggunya infrastruktur PLN sehingga terputusnya supply listrik termasuk ke rumah-rumah penduduk. Sementara itu, pompa air yang bekerja karena adanya pasokan listrik PLN umumnya digunakan oleh masyarakat dalam memenuhi kebutuhan air sehari-hari. Jika terjadi pemutusan aliran listrik, maka penyediaan air ikut terputus. Oleh karena itu pompa air bertenaga gabungan generator diesel/sel surya/baterai menjadi salah satu solusinya.

Sel surya sebagai salah satu sumber energi baru yang terbarukan menjadi salah satu pilihan karena letak Indonesia di garis equator yang mendapatkan sinar 
Volume 5 Nomor. 1, April 2020

P -ISSN : 2541-1179, E-ISSN : 2581-1711

Ojs :http://journal.uin-alauddin.ac.id/index.php/instek/index

Email : instek@uin-alauddin.ac.id

matahari sepanjang tahun. Selain itu juga Tamer berpendapat bahwa sel surya merupakan teknologi ramah lingkungan dan sumber energi yang aman tetapi biaya instalasi awal dari panel photovoltaic (PV) ini cukup mahal dibandingkan sumber energi konvensional. Sehingga banyak penelitian-penelitian terdahulu yang dilakukan untuk mengoptimalkan penggunaan PV sebagai sumber energi dan pemanfaatan sumber listrik hybrid PV dengan sumber energi lainnya. Model optimasi Ren selain memperlihatkan strategi operasi optimal hybrid PV/fuel cell/battery untuk perumahan, juga meminimalkan biaya operasi tahunan dan emisi $\mathrm{CO}_{2}$. Bagirov mengoptimalkan operasi sistem distribusi air untuk mengurangi penggunaan daya sehingga dapat mengurangi biaya energy dan biaya perawatan yang lebih rendah. Kanwarjit menyatakan strategi pengaturan demand pada sistem energi hibrida $\mathrm{PV} /$ angin/baterai menggunakan filter energi mampu mengurangi jumlah elemen penyimpanan energi yang dibutuhkan sehingga menghasilkan biaya per unit listrik yang lebih sedikit.

Pada penelitian ini optimasi PATH menggunakan metode linear programming dengan tujuan meminimalisir penggunaan bahan bakar. Sehingga pengoperasian generator diesel yang membutuhkan bahan bakar sebagai alternatif terakhir dalam memberikan daya listrik agar pompa air bekerja melayani ketersediaan air bagi pelanggan.

\section{METODE PENELITIAN}

Batasan-batasan pada sistem PATH mempertimbangkan permintaan air, daya yang dibutuhkan untuk menggerakkan pompa air, tangki penyimpanan air setiap saat terisi $1 \mathrm{~m}^{3}$ dan kapasitas baterai selalu 100\% setiap memulai hari. Batasanbatasan penyediaan air dinyatakan melalui persamaan-persamaan berikut ini

$$
Q_{k}^{\text {pompa }} \geq 0
$$




$$
\begin{aligned}
& Q_{\min }^{\text {pompa }} \leq Q_{k}^{\text {pompa }} \leq Q_{\max }^{\text {pompa }} \\
& V_{\min }^{\text {tangki }} \leq V_{k}^{\text {tangki }} \leq V_{\max }^{\text {tangki }} \\
& V_{25}^{\text {tank }} \geq V_{1}^{\text {tank }}
\end{aligned}
$$

Selanjutnya, pertimbangan kendala-kendala berkaitan dengan daya dinyatakan dalam

$$
\begin{aligned}
& p_{k}^{D G} \geq 0 \\
& P_{\min }^{D G} \leq P_{k}^{D G} \leq P_{\max }^{D G} \\
& S o C_{\min } \leq \operatorname{SoC}_{k} \leq S o C_{\max } \\
& \operatorname{SoC}_{25} \geq \operatorname{SoC}_{1}
\end{aligned}
$$

dengan $k=1,2, \ldots, 24$

dimana $P_{k}^{\text {pompa }}$ adalah daya pompa pada jam $\mathrm{k}(\mathrm{kW}), P_{j, k}^{P V}$ menyatakan daya solar sell pada saat $\mathrm{j}$ atau jam $\mathrm{k}(\mathrm{kW}), P_{j, k}^{\text {batt }}$ adalah daya baterai pada saat $\mathrm{j}$ atau jam $\mathrm{k}$ $(\mathrm{kW}), Q_{j, k}^{\text {dem }}$ adalah laju debit air yang butuhkan pengguna pada saat $\mathrm{j}$ atau jam $\mathrm{k}$ $\left(\mathrm{m}^{3} / \mathrm{h}\right), Q_{j, k}^{\text {pompa }}$ yaitu laju debit air yang dihasilkan pompa pada saat $\mathrm{j}$ atau jam $\mathrm{k}$ $\left(\mathrm{m}^{3} / \mathrm{h}\right), Q_{\min }^{\text {pompa }}$ ialah laju debit air minimum pompa $\left(\mathrm{m}^{3} / \mathrm{h}\right), Q_{\max }^{\text {pompa }}$ menyatakan laju debit air maksimum pompa $\left(\mathrm{m}^{3} / \mathrm{h}\right), P_{k}^{D G}$ adalah daya generator diesel pada jam $\mathrm{k}(\mathrm{kW}), P_{\text {min }}^{D G}$ adalah daya generator diesel minimum pada jam $\mathrm{k}(\mathrm{kW}), P_{\text {max }}^{D G}$ merupakan daya generator diesel maksimum pada jam $\mathrm{k}(\mathrm{kW})$, $S o C_{k}$ kondisi pengisisan baterai pada jam $\mathrm{k}(\%), S o C_{1}$ ialah kondisi baterai pada jam pertama $(\%), S o C_{\min }$ kondisi minimum baterai (\%), $S o C_{\max }$ ialah kondisi maksimum baterai (\%), $V_{k}^{\text {tangki }}$ volume air di penampungan pada jam k (\%), $V_{\min }^{\text {tangki }}$ volume air minumum di penampungan (\%), dan $V_{\max }^{\text {tangki }}$ adalah volume air maksimum di penampungan $(\%)$.

Flowchart sistem PATH tampak pada dua gambar berikut ini. Gambar 6 memperlihatkan kondisi penampung air (WT) selalu bernilai $1 \mathrm{~m}^{3}$ dan daya baterai di jam pertama tiap harinya selalu $100 \%$. Juga memastikan proses looping selama satu tahun. 


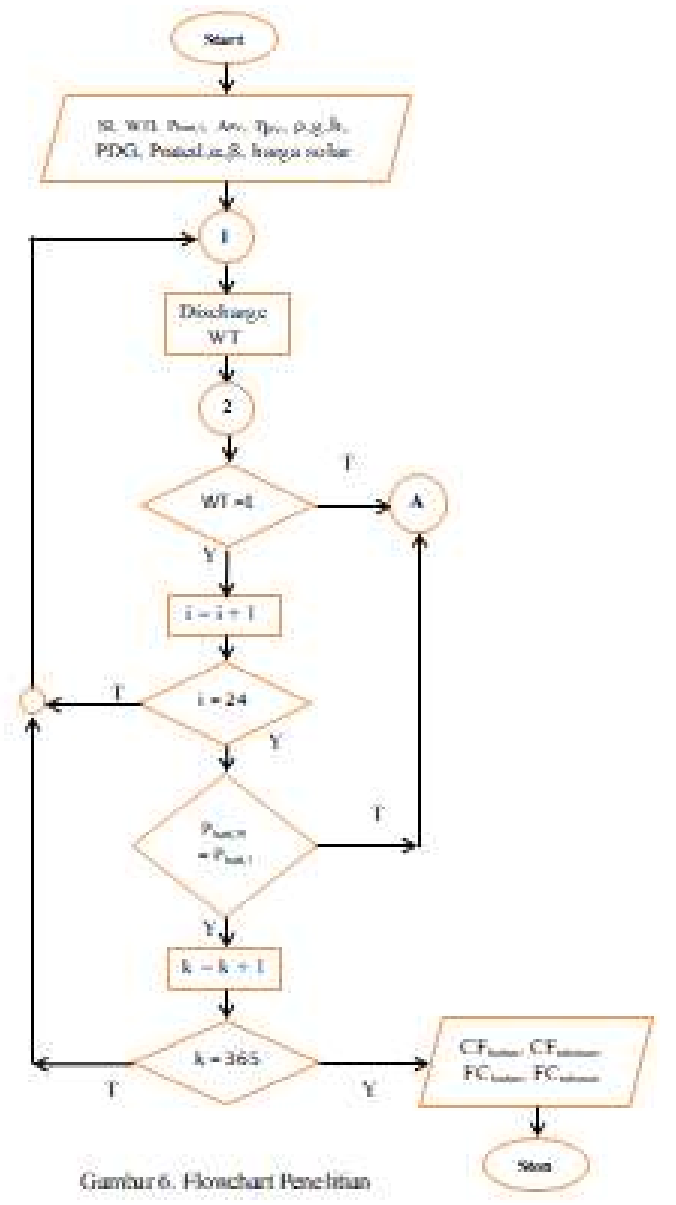

Gambar 1. Flowchart Penelitian

Sedangkan gambar 2 memperlihatkan proses supply daya agar pompa air bekerja, pengisian dan pengosongan baterai serta mengisi penampungan air disaat ada permintaan air yang mengakibatkan air di tangkinya tidak penuh. Lebih lanjut, pengaturan sumber daya yang menggerakkan pompa air. Pertama-tama pasokan sumber daya PV yang akan menggerakkan pompa. Jika daya PV masih belum mampu menyediakannya, maka kapasitas baterai akan berkurang untuk mengisi defisit daya tersebut. Sedangkan jika daya PV berlebih maka kelebihan daya tersebut akan mengisi baterai. Pada saat SoC baterai penuh dan masih ada surplus daya maka daya berlebih tersebut akan dibuang. Proses pengisian tangki air akan dilakukan jika daya PV atau daya PV dan baterai sama atau lebih dari daya yang dibutuhkan pompa air beroperasi. Generator diesel akan bekerja pada saat pasokan 
Volume 5 Nomor. 1, April 2020

P -ISSN : 2541-1179, E-ISSN : 2581-1711

Ojs :http://journal.uin-alauddin.ac.id/index.php/instek/index Email : instek@uin-alauddin.ac.id

daya PV dan baterai tidak mencukupi kebutuhan daya pompa. Kekurangan daya tersebut diisi oleh generator diesel.

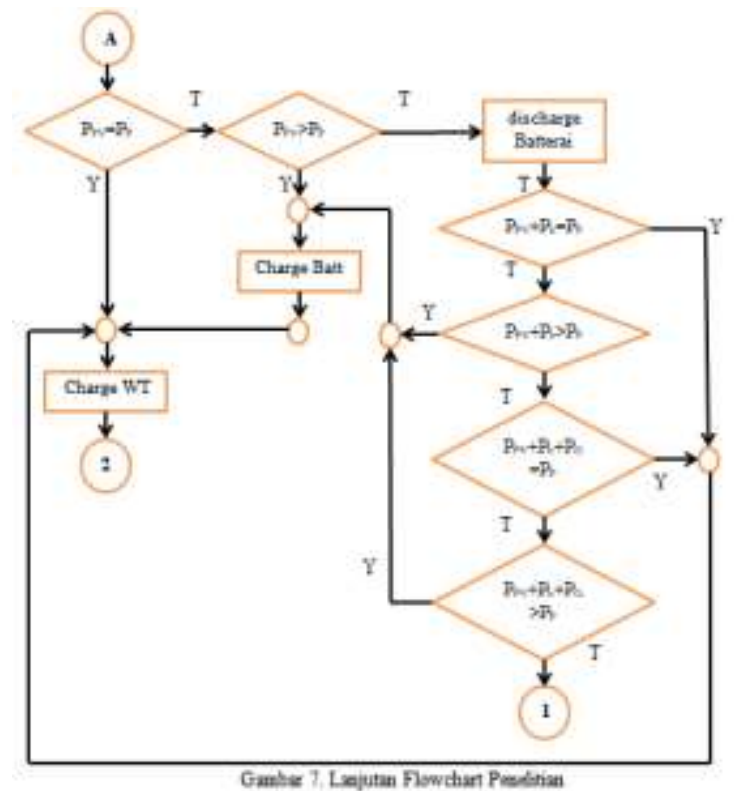

Gambar 2. Lanjutan Flowchart Penelitian

Controller bukan hanya mengatur kondisi on-off-idlenya baterai, tetapi mengatur juga on off-nya generator diesel.

Inisialisasi awal tangki air dan kapasitas baterai tampak seperti pada tabel 1 berikut ini

Tabel 1. Kondisi awal tangki air dan baterai

\begin{tabular}{|c|c|c|c|c|}
\hline \multirow{2}{*}{ No } & \multirow{2}{*}{$\begin{array}{c}\text { Solar Sel } \\
(W p)\end{array}$} & Baterai & \multicolumn{2}{|c|}{ Kondisi Awal } \\
\cline { 4 - 5 } & $(\mathrm{Ah}, 12 \mathrm{~V})$ & Tangki Air (m3) & Baterai (\%) \\
\hline 1 & 50 & 20 & 0 & 20 \\
\hline 2 & 50 & 20 & 0 & 100 \\
\hline 3 & 50 & 20 & 1 & 20 \\
\hline 4 & 50 & 20 & 1 & 100 \\
\hline
\end{tabular}

\section{Konsumsi Bahan Bakar}

Generator diesel membutuhkan bahan bakar dalam pengoperasiannya. Jumlah bahan bakar setiap jamnya dapat dimodelkan menggunakan linear law berdasar padaa daya output generator yang dibutuhkan. Banyaknya bahan bakar yang dibutuhkan generator beroperasi tiap jam dinyatakan sebagai berikut (Ismail, 2013):

$$
C F(t)=\propto_{D G} * P(t)_{D G}+\beta_{D G} * P_{r a t, D G}
$$

dimana $\quad \mathrm{CF}(\mathrm{t})$ merupakan jumlah bahan bakar pada saat $\mathrm{t}$ (liter/jam), $\alpha_{\mathrm{DG}}$ dan $\beta_{\mathrm{DG}}$ berturut-turut bernilai 0,246 (1iter/kWh) dan 0,08145 (liter/kWh). $\mathrm{P}(\mathrm{t})_{\mathrm{DG}}$ 
Volume 5 Nomor. 1, April 2020

P -ISSN : 2541-1179, E-ISSN : 2581-1711

Ojs :http://journal.uin-alauddin.ac.id/index.php/instek/index

Email : instek@uin-alauddin.ac.id

adalah daya generator tiap jamnya $(\mathrm{kW})$ dan $\mathrm{P}_{\text {rat,DG merupakan daya rated }}$ generator $(\mathrm{kW})$

\section{III.HASIL DAN PEMBAHASAN}

Pengaturan energi sistem PATH pada penelitian ini memperhatikan kondisi awal dari ketersediaan air di tangki dan kapasitas baterai yang ada. Terdapat empat skenario berdasarkan tabel 1 . Semua skenario menggunakan 1 modul PV berkapasitas $50 \mathrm{Wp}$ dan baterai 20 Ah dengan tegangan kerjanya $12 \mathrm{~V}$.

Skenario pertama merupakan sistem kelola energi PATH dimana kondisi awal penampungan air kosong dan baterai terisi pada SoC minimal sebesar 20\%. Keadaan ini menyebabkan generator diesel harus dioperasikan untuk mengisi penuh salah satu penampungan air atau baterai. Kemungkinan yang lain adalah mengisi 1 m3 air ke penampungan (43,795 W) dan kapasitas baterai sebesar 80\% (192 W). Optimasi sistem meminimalisir penggunaan konsumsi bahan bakar tetapi karena constraint yang menentukan bahwa penampungan air harus selalu penuh, maka pada jam pertama hari pertama ini generator digunakan untuk mengisi tangki air dan baterai sampai 100\%. Pada saat matahari sudah tenggelam, baterai discharging untuk menyalakan pompa sehingga tetap mampu melayani penggunaan air dan isi tangki air selalu 100\%. Pada akhir hari, baterai kembali diisi sampai berkapasitas $0,24 \mathrm{~kW}$.

Pengaturan energi PATH pada skenario kedua berposisi awal penampungan air kosong dan baterai terisi $100 \%$. Keadaan ini menyebabkan generator diesel harus dioperasikan untuk mengisi penuh penampungan air. Daya generator yang dibutuhkan untuk menggerakkan pompa sehingga tangki air bervolume $1 \mathrm{~m} 3$ dapat terisi sebesar 43,795 W.

Skenario ketiga mengatur energi PATH berkondisi mula-mula air di tangki terisi penuh sedangkan baterai terisi 20\%. Posisi SoC terendah baterai 20\%. Pada state $P_{P V}<P_{\text {pompa }}$ dan baterai pada kapasitas terendahnya, maka baterai tidak dapat lagi dipergunakan untuk menyuntikkan daya agar pompa air dapat bekerja. Hal ini dilakukan untuk memperpanjang lifecycle baterai. Keadaan ini menyebabkan 
P -ISSN : 2541-1179, E-ISSN : 2581-1711

Ojs :http://journal.uin-alauddin.ac.id/index.php/instek/index Email : instek@uin-alauddin.ac.id

generator diesel harus terlebih dahulu dioperasikan untuk mengisi $80 \%$ daya baterai yaitu sebesar $192 \mathrm{~W}$ untuk selanjutnya tetap dapat melayani permintaan air di awalawal sistem PATH ini.

Skenario terakhir posisi awal penampungan air dan baterai penuh. Pada keadaan awal ini generator tidak perlu dinyalakan. Awalnya baterai menyuntikkan daya untuk menggerakkan pompa saat $P_{P V}<P_{\text {pompa }}$ untuk melayani permintaan air. Jika nilai $P_{P V} \geq P_{\text {pompa }}$ telah terealisasi, maka baterai akan stop discharging. Selanjutnya baterai akan mulai charging jika $P_{P V}>P_{\text {pompa }}$ sampai controller menghentikan proses pengisian ini saat kapasitas baterai telah 100\%.

Konsumsi bahan bakar untuk keempat skenario selang setahun pengamatan dapat dilihat pada gambar di bawah ini

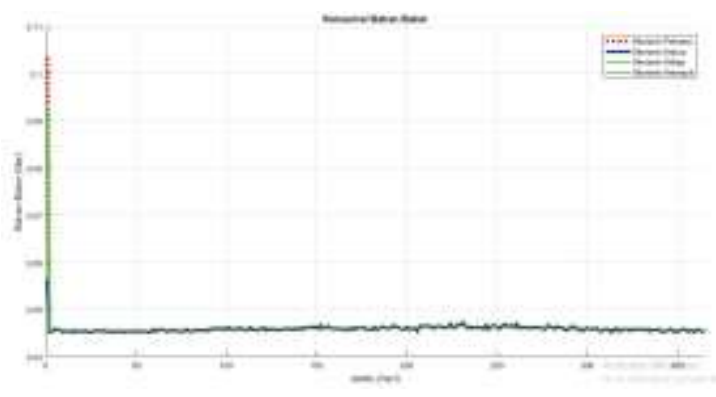

Gambar 3. Konsumsi bahan bakar

Besarnya penggunaan daya generator sebanding dengan besarnya bahan bakar yang dibutuhkan. Terlihat bahwa perbedaan konsumsi bahan bakar untuk semua skenario PATH terjadi di hari pertama simulasi ini dijalankan. Sementara waktuwaktu yang lainnya, generator membutuhkan bahan bakar yang sama. Konsumsi bahan bakar selama 365 untuk skenario pertama adalah 16,784 liter, sedangkan skenario kedua sebesar 16,737 liter. Bahan bakar yang dibutuhkan selama setahun pada skenario ketiga dan keempat secara berturut-turut adalah 16,773 liter dan 16,726 liter.

\section{KESIMPULAN}

PATH dipergunakan untuk menyediakan air dalam satu rumah dapat diterapkan dengan menginstall 1 panel surya berdaya $50 \mathrm{Wp}$, sebuah baterai berkapasitas 20 Ah dan bertegangan $12 \mathrm{~V}$ dan satu penampung air bervolume $1 \mathrm{~m}^{3}$. Konsumsi bahan 
Volume 5 Nomor. 1, April 2020

P -ISSN : 2541-1179, E-ISSN : 2581-1711

Ojs :http://journal.uin-alauddin.ac.id/index.php/instek/index

Email : instek@uin-alauddin.ac.id

bakar optimum diperoleh pada saat kondisi awal tangki air terisi full dan kapasitas penyimpan baterai $100 \%$.

\section{DAFTAR PUSTAKA}

A. Bagirov, J. Ugon, A. Barton dan S. Briggs, Optimization of Operations of a Water Distribution System for Reduced Power Usage, 9th National Conference on Hydraulics in Water Engineering, Darwin - Australia, September 2008.

Abdelhamid Kaabeche, Rachid Ibtiouen, Techno-Economic Optimization of Hybrid Photovoltaic/Wind/Diesel/Battery Generation in A Stand-Alone Power System, ScienceDirect, Solar Energy, Volume 103, halaman 171 - 182, 2014.

Amos Madhlopa, Debbie Sparks, Samantha Keen, Mascha Moorlach, Pieter Krog, Thuli Dlamini, Optimization of a PV-wind hybrid system underlimited water resources, Renewal and Sustainable Enegy Review, Volume 47, halaman $324-331,2015$.

E.M. Nfah, J.M. Ngundam, R. Tchinda, Modelling of solar/diesel/battery hybrid power systems for far-north Cameroon, Renewable Energy 32, halaman 832-844, 2007

Hicham Fakham, Di Lu, Bruno Francois, Power Control Design of a battery charger in a Hybrid Active PV generator for load-following applications, IEEE Transaction on Industrial Electronics, Vol. 58, Iss. 1, halaman 8594, Jan. 2011.

H. Ren, Q. Wu, W. Gao, and W. Zhou, Optimal operation of a grid-connected hybrid PV/fuel cell/battery energy system for residential applications, Energy, vol. 113, pp. 702-712, 2016.

Kanwarjit Singh Sandhu and Aeidapu Mahesh, Optimal sizing of PV/wind/battery Hybrid Renewable Energy System Considering Demand Side Management, International Journal on Electrical Engineering and Informatics, Volume 10, Nomor 1, Maret 2018

K. Karakoulidis, K. Mavridis, D. V. Bandekas, dkk, Techno-Economic Analysis of A Stand-Alone Hybrid Photovoltaic-Diesel-Battery-Fuel Cell Power System, Renewable Energy, Volume 36, halaman 2238 - 2244, 2011. 